\title{
Szkic fizjologiczny jako gatunek mowy
}

\author{
Artur Rejter
}




\section{Artur Rejter}

\section{Szkic fizjologiczny jako gatunek mowy}

$\mathrm{W}$ e współczesnej humanistyce można zaobserwować od pewnego czasu wyraźną tendencję do interdyscyplinarnego traktowania przedmiotu badań. W wyniku tego pojawia się możliwość płodnej współpracy różnych dziedzin naukowych, takich jak literaturoznawstwo, lingwistyka, socjologia, psychologia, antropologia itp. Szerokie i wszechstronne traktowanie działalności człowieka wraz z zastosowaniem różnych rozwiązań metodologicznych pomaga wysnuć wnioski o charakterze generalizującym, znaczące dla różnych gałęzi wiedzy. Jednym z przejawów popularności pluralizmu poznawczego są badania nad szeroko pojętą komunikacją językową.

Wymiana informacji za pomocą języka opiera się na wykorzystaniu bogatego repertuaru wzorców komunikacyjnych nazywanych gatunkami mowy ${ }^{1}$ (genrami mowy) ${ }^{2}$. Gatunki mowy powstałe w wyniku przemian kulturowych prowokujących przemiany komunikacyjne nazywa się gatunkami wtórnymi, w odróżnieniu od gatunków pierwotnych pojmowanych jako elcmenty przetworzenia ${ }^{3}$, baza dla gatunków wtórnych. Próby typologii i klasyfikacji gatunkowych odmian wypowiedzi stanowią przedmiot zainteresowań genologii lingwistycznej ${ }^{4}$.

\footnotetext{
' Zob. M. Bachtin, Estetyka nuórczości stownej, tt. D. Ulicka, Warszawa 1986, s. 348-402.

2 Zob. A. Wierzbicka, Genry moury, [w:] Tekst i zdanie. Zbiór studiów, red. T. Dobrzyńska, E. Janus, Wrocław 1983, s. 125-137.

${ }^{3}$ O Bachtinowskim dychotomicznym rozumieniu pojęcia „wtórny gatunek mowy” zob. T. Dobrzyńska, O gatunkach pienvotnych i utónizych. (Czztając Bachtina), [w:] Typy tekstów. Zbiór studiów, red. T. Dobrzyńska, Wrocław 1992, s. 75-80. Oprócz przyjętego w niniejszej pracy rozumienia terminu autorka wspomina także o definiowaniu wtórnego gatunku mowy jako charakterystycznego dla pierwotnego (przedpiśmiennego) etapu komunikacji międzyludzkiej.

${ }^{4}$ Zob. np.: A. Furdal, Genologia lingwistyczna, „Biuletyn Polskiego Towarzystwa Językoznawczego”, 1982, s. 62-71; S. Gajda, Gatunkowe uzorce wypouviedzi, [w:] Encyklopedia kultury polskiej XX wieku, t. 2: Wspólczesny jezyk polski, red. J. Bartmiński, Wrocław 1993, s. 245-258; A. Wierzbicka, op. cit.
} 
W niezwykle złożonym i bogatym uniwersum gatunków mowy kojarzonych z masową komunikacją szczególne miejsce zajmuje szkic fizjologiczny. Celem niniejszego artykułu jest wskazanie jego cech konstytutywnych jako gatunku wypowiedzi, które pomogą dookreślić definicję tego bytu językowo-stylistycznego, a także sprecyzować funkcje, jakie pełnił w dziewiętnastowiecznej rzeczywistości komunikacyjnej, wyznaczonej przez niezwykle intensywny rozwój gatunków o szerokim zasięgu, motywowany wzrostem roli prasy jako podstawowego środka masowego przekazu.

Szkic fizjologiczny (przykład wtórnego gatunku mowy) to odmiana genologiczna o charakterze zdecydowanie efemerycznym — pojawia się na początku XIX wieku, jej największy rozkwit przypada na lata czterdzieste tego stulecia ${ }^{5}$, a na początku wieku XX już właściwie nie jest uprawiana w swej czystej formie ${ }^{6}$. W Polsce szkic fizjologiczny nie rozwijał się tak intensywnie jak na Zachodzie Europy, co wiązało się z pewnym opóźnieniem ekonomiczno-społecznym naszego $\mathrm{kraju}^{7}$, niemniej gatunek ten pojawia się w różnych tytułach prasowych na terenie całej Polski.

Najogólniej rzecz ujmując, szkic fizjologiczny zalicza się do prozy narracyjnej o pewnym nacechowaniu satyrycznym lub dydaktycznym ${ }^{8}$. Jest to zatem odmiana o przeznaczeniu użytkowym, na co zresztą wskazuje jej geneza. Powszechność szkicu fizjologicznego bowiem wiąże się z przypadającym właśnie na pierwszą połowę XIX wieku ${ }^{9}$ ekspansywnym rozwojem prasy, zwłaszcza popularnej, która na swych łamach drukowała tego typu teksty ${ }^{10}$, jak również z ówczesną fascynacją osiągnięciami nauk przyrodniczych (stąd właśnie „biologiczna" nazwa gatunku mowy) ${ }^{11}$.

Autorzy „fizjologii” skupiali wysiłek na „naukowej” analizie społeczeństwa, co wtedy oznaczało wyodrębnienie typów socjalnych, monograficzny opis warstw społecznych, grup zawodowych, marginesowych środowisk, ale przede wszystkim - ich statyczną klasyfikację tworzoną na podobieństwo opracowywanych przez słynnych biologów-ewolucjonistów (Lamarck). W opisach tego rodzaju wykorzystywano również pozornie usystematyzowaną wiedzę potoczną, pseudorygorystyczną charakterologię, ,naukę o temperamentach" bądź też niezwykle modną „fizjonomikę"12.

${ }^{5}$ Zob. P. Stasiński, Poetyka i pragmatyka felietonu, Wrocław 1982, s. 36.

- Zob. J. Rosnowska, Wstęp [do:] Polacy przez siebie samych odmalowani. Szkice fizjologiczne 1833-1862, wstęp i wyb. J. Rosnowska, oprac. C. Gajkowska, Kraków 1979, s. 15. Autorka wspomina o powolnym zaniku cech literackich na rzecz socjologicznych bądź humorystycznych.

${ }^{7}$ Zob. tamże, s. 12.

${ }^{8}$ Zob. M. Głowiński, T. Kostkiewiczowa, A. Okopień-Sławińska, J. Sławiński, Słownik terminów literackich, Wrocław 1989, s. 511.

${ }^{9}$ Zob. P. Stasiński, op. cit., s. 36.

${ }^{10}$ Zaznaczyć jednak należy, że szkice fizjologiczne były wydawane także w formie osobnych zbiorów, zarówno w Polsce, jak i za granica. Por. J. Rosnowska, op. cit., s. 5-6.

$"$ Zob. P. Stasiński, op. cit.; J. Rosnowska, op. cit., s. 7.

12 P. Stasiński, op. cit., s. 36-37. 
Celem autorów szkiców fizjologicznych było zatem przedstawienie wizerunku typu, przybliżenie konkretnego egzemplarza nie znajdowało się w kręgu ich zainteresowań:

Typ, gatunek - nie osoba, nie indywiduum - był obiektem opisu. Jak w stworzonej przez Linneusza systematyce roślin nie chodziło o kwiat konkretny, rosnący na konkretnej łące, lecz o oznaczenie, do jakiego gatunku, rodzaju, rzędu i klasy należą wszystkie kwiaty o danej liczbie i danym układzie pręcików i słupków, tak literaci — autorzy fizjologii — nie tworzyli konkretnej postaci ekonoma czy panny na wydaniu, lecz określali cechy, które stanowiły o tym, że ktoś jest ekonomem czy panną na wydaniu, ewentualnie — jakiego "gatunku” ekonomem, jakiego „gatunku” panną na wydaniu ${ }^{13}$.

Owa typowość, będąca głównym przedmiotem obserwacji, jako wyznacznik gatunkowy jest widoczna już w tytułach poszczególnych szkiców fizjologicznych: Ekonom, Uliczni handlarze warszawscy, Krewni, Stare panny, Górale tatrańscy, Piaskowcy, Fizjologia dozorcy, Goście, Modnis, Pieczeniarz, Galeria panien, Wiściarze, Literat mtody, Magnaci gietdowi, Kupcy, Ogrodnicy ${ }^{14}$. Jak widać, autorzy pragnęli tytułem zasygnalizować cel komunikatu, celem tym był portret prototypowego przedstawiciela danego typu społecznego.

Istotną cechą gatunkową szkicu fizjologicznego jest wyrażana językowo relacja nadawczo-odbiorcza ${ }^{15}$ polegająca na sygnalizowaniu przez nadawcę wspólnoty poglądów, stereotypów społecznych, przekonań, interpretacji faktów, słowem: wspólnoty rzeczywistości percypowanej. Nadawca konstruuje wywód z dużym „wyczuciem” odbiorcy, co świadczy o istocie uobecnienia odbiorcy w płaszczyźnie tekstu.

Ujrzałeś go na każdej przechadzce, w każdej kawiarni, na każdej maskaradzie, gdzie tylko hulanka, swawola, gdzie wesołość, śmiechy. (...) Nie ujrzałeś wówczas swobodnie przechadzających się, wysiadujących po kawiarniach godziny całe.

$$
\text { Józef Ignacy Kraszewski, Akademik (s. 196) [1] }
$$

Przedstawiany obraz okazuje się — dzięki użyciu form drugiej osoby liczby mnogiej czasownika - wspólnym dla nadawcy i odbiorcy, przez co relacja staje się niezwykle sugestywna i wiarygodna. Odbiorca uczestniczy niejako w opisywanej sytuacji.

Uskarżaliście się częstokroć z narzekaniem, kochani czytelnicy nasi, iż „Bałamut” zbytnie nawiedzanym bywał od wiernego naszego Izraela.-- Ale,

\footnotetext{
${ }^{13} \mathrm{~J}$. Rosnowska, op. cit., s. 10.

14 Wszystkie przykłady pochodzą z cytowanego wydania: Polacy przez siebie samych odmalowani... (w nawiasach numery stron)

${ }^{15}$ Nadawca i odbiorca w komunikacji literackiej przynależą do zewnątrztekstowego poziomu komunikacji. $\mathrm{Na}$ poziomie wewnątrztekstowym nadawcy odpowiada podmiot utworu, odbiorcy zaś adresat utworu. Zob. A. Okopień-Sławińska, Relacje osoboue w literackiej komunikacji, [w:] taż, Semantyka wypowiedzi poetyckiej (Preliminaria), Kraków 1998, s. 100-116.
} 
z drugiej strony, zastanówcie się tylko, proszę, czytelnicy, w co by się obróciła biedna nasza kraina, jeśli by plemię żydowskie nagle z niej znikło.

anonim, Fizjologia dozorcy (s. 206-207) [2]

Solidaryzowanie się z odbiorcą zacieśnia kontakt między podmiotami komunikacji, umożliwia jednocześnie polemikę dynamizującą dyskurs. Interakcja zostaje dookreślona przez zastosowanie leksemu „czytelnicy”, jak również zacieśniona dzięki epitetom „kochani” i „nasi”. Pozbawiona aspektu oficjalności relacja nadawczo-odbiorcza zdecydowanie ułatwia nadawcy argumentację.

Patrzcie na tego panicza, jak w paletonie najświeższej mody przechadza się po stronie południowej rynku; z jaką gracją oddaje znajomym ukłony i zdobywanym damom pod kapelusze zagląda (...).

Stanisław Jaszowski, Modniś (s. 217) [3]

Fragment powyższy także dowodzi znacznego zbliżenia nadawcy i odbiorcy poprzez uzycie formy imperatywnej. Ponadto uwaga odbiorcy skierowana zostaje na przedmiot podlegający drobiazgowej deskrypcji w dalszych partiach komunikatu. Uwypuklenie postaci panicza przygotowuje niejako odbiorcę do detalicznej charakterystyki typu społecznego.

Ale przebaczmy tej pani, jeżeli nam się tak bardzo podobała — w nicj tyle tylko winy, że trochę za wiele liczy na swój ubiór, którego nawet używać nie umie.

Józef Symeon Bogucki, Wojna na ubiory, (s. 243) [4]

Ten przykład wskazuje na zastosowanie formy trybu rozkazującego w celu zjednania sobie odbiorcy - nadawca pragnie w pewnym stopniu zdystansować się od opisywanego wcześniej problemu. Przytoczony fragment pochodzi z końcowych partii szkicu, nadawca chciał zapewne złagodzić przedstawioną wyżej krytyczną charakterystykę typu społecznego.

Jak widać z przytoczonych przykładów, uobecnianie odbiorcy w strukturze komunikatu służy przede wszystkim zbliżeniu relacji nadawczo-odbiorczej, co ma spełniać różnorodne funkcje. Wśród nich wymienić należy:

- uwiarygodnienie przekazu (zasada mimetyzmu, przykład 1.);

- złagodzenie perswazji (przykład 2.);

- zwrócenie uwagi na przedmiot charakterystyki (przykład 3.);

- złagodzenie krytycznego tonu przedstawianych charakterystyk (przykład 4.).

Poza relacją nadawczo-odbiorczą warto przyjrzeć się podstawowym strukturom wypowiedzi i ich funkcjom w płaszczyźnie tekstu szkiców fizjologicznych. Analizowany gatunek mowy wskazuje na specyficzne funkcje zarówno opisu, jak i opowiadania.

Opis służy w obserwowanych tekstach charakterystyce typów społecznych, bądź to w rozumieniu ogólnym (grupa), bądź też w rozumieniu idealnego/prototypowego egzemplarza (przykład jednostkowy - prototyp). Wśród wielu form opisu zaobserwowanych w szkicach 
fizjologicznych kilka zasługuje na szczególną uwagę ze względu na frekwencję lub niepowtarzalność i stopień oryginalności.

Jedną z form, jaką opis przyjmuje, jest postać definicji:

Jest to najdziwaczniejszy utwór babi; krokodyl z niewieściego rodzaju.

Rzemiosło przekupek jest szeroko rozgałęzione w Polszcze, są różne zatem ich rodzaje; pierwszy i najprzedniejszy rodzaj: przekupek warszawskich.

Kazimierz Władysław Wójcicki, Przekupka warszawska (s. 173)

Definicję cechuje jednolita struktura i jednoznaczność deskrypcji, podanie zbioru istotnych cech opisywanego przedmiotu ${ }^{16}$. W powyższym przykładzie jednak posłużono się emocjonalnymi porównaniami, ekspresywizmami. Całość sprawia więc raczej wrażenie parodii niz prawdziwej definicji. Niemniej zachowane zostały istotne cechy definicji: klarowność i uporządkowanie treści (podanie typu przekupki). Opis ujęty w postać definicji pozwala w skondensowanej formie przekazać maksimum treści, co w przypadku portretowania typów jest niezwykle ważne.

Kolejną formą deskrypcji jest rozbudowane wyliczenie:

Cała populacja wileńska pewien rodzaj szacunku miała dla akademika: bo młody, często trzpiot, figlarz, impertynent, szyderca, naprzykrzony mial serce najlepsze i szlachetność w charakterze. (...) Powiedziałem akademik miał wiele zdrożności, ułomności wiekowi swemu właściwych, właściwych stanowi swemu, ale w gruncie ślachetny byl, poświęcający się, czuły, poczciwy.

J. I. Kraszewski, Akademik (s. 192)

Wyliczenie - podobnie jak definicja - zapewnia maksimum treści przy jednoczesnej skondensowanej formie. Ponadto umożliwia precyzyjną charakterystykę przedmiotu poddanego deskrypcji dzięki ciągom określeń bohatera, będących kośćcem przytoczonej enumeracji. Niebanalne znaczenie mają również zastosowane synonimy w budowaniu wymiaru ekspresywnego wypowiedzi.

Opis w szkicu fizjologicznym może być także oparty na swoistej kreacji o nadrzędnym wymiarze indywidualistycznym (artystycznym):

\section{Niedźwiedzie}

Niedźwiedzie najchętniej po wsiach się sadowią. Człowiek-niedźwiedź zawsze nadęty: grzeczność i uprzejmość poczytuje za słabość charakteru i unika tych przymiotów, rozumiejąc, że jego niedźwiedzia mość ubliżyłaby swej ogromnej godności, gdyby dla kogokolwiek grzeczność i uprzejmość okazała.

${ }^{16}$ Zob. B. Witosz, Opis w prozie narracyjnej na tle innych odmian deskrypcji. Zagadnienia struktury tekstu, Katowice 1997, s. 124. 
Zwykle niedźwiedzie chorują na suchoty mózgowe, ale co do ciała, na samejże personie są w kwitnącym stanie. Stare niedźwiedzie miewają czasem tę istotną zaletę, że są szczere, otwarte i rzetelne w słowie; u młodych niedźwiedzi i o te zalety najczęściej na próżno się spytasz. Niezgoda w publicznym, gnuśność w prywatnym życiu są także niedźwiedziemu rodowi nieodłączne. Żyją wystawnie z pracy ludzi innego gatunku.

August Wilkoński, Szkice psychologiczne niektórych ludzi-zwierząt (s. 226)

Deskrypcja przyjmuje tutaj formę alegorii w pewnym stopniu udosłownionej, to znaczy postać niedźwiedzia nie jest zamiennikiem człowieka, ale stanowi źródło bezpośredniego (eksplicytnego) porównania istoty ludzkiej do zwierzęcej. Ponadto nie można mówić w powyższym przykładzie o przekazywaniu cech abstrakcyjnych, złożonych ${ }^{17}$ za pomocą ukrytego odniesienia człowiek-niedźwiedź - nazwa animalistyczna jest tutaj tylko nośnikiem wyrazistego opisu typu społecznego. Cały szkic zresztą jest zbiorem portretów ludzi-zwierząt, które służą pewnej nacechowanej artystycznie kategoryzacji świata.

Obok opisu także opowiadanie, jako druga z podstawowych struktur wypowiedzi, wykazuje określony zasób funkcji pomagających wyabstrahować szkic fizjologiczny z uniwersum gatunków mowy. Fragmenty o nacechowaniu sprawozdawczym służą pogłębieniu, uwiarygodnieniu informacji zawartych we fragmentach deskryptywnych:

Bonifacemu jadłospis z rąk wyleciał, twarz przedłużyła się o kilka cali, a na zapytanie posługacza, co sobie dać każe, ponurym głosem zażądał gazety, wczytał się w jej stronice i ani już pomyślał o jadle. Z godzinę przerzucał gazetę, nawet dodatki odczytał, a widząc, że już po jedenastej i Alfred nie powraca ani powrócić myśli, skromnie na własny koszt kazał sobie dać kieliszek wódki i kiełbaski z sosem, po czym, z westchnieniem pożegnawszy się z obecnymi w wyobraźni jego węgorzem i biwsztykiem, mrucząc na zepsucie obyczajów i lekkomyślność młodzieży, znowu na miasto wyszedł.

S. Jaszowski, Pieczeniarz (s. 232)

Przytoczony fragment opowiadania służy pogłębieniu charakterystyki typu społecznego, którego przykładem w tekście jest pan Bonifacy (przykład typu społecznego), poprzez przytoczenie jednostkowego wydarzenia. Opowiadanie konstruuje charakterystykę pośrednią i umacnia elementy zawarte $w$ opisie umiejscowione $w$ innych partiach tekstu, jakimi są łakomstwo i skąpstwo głównego bohatera - typu społecznego. Jak widać, fragmenty sprawozdawcze są wyraźnie służebne wobec deskrypcyjnych, zapewniających charakterystykę bezpośrednią. Ich mniejsze potwierdzenie frekwencyjne w badanym gatunku mowy dodatkowo potwierdza tę tezę.

17 Taką funkcję podaje się jako definicyjną w przypadku alegorii. Zob. M. Głowiński, T. Kostkiewiczowa, A. Okopień-Sławińska, J. Sławiński, op. cit., s. 23. 
Nasz modniś budzi się, ziewa, nakłada fajkę i w łóżku pali jak sułtan. Przysunął krzesło do łóżka i stuknięcie to zapewne usłyszano za drzwiami, bo dało się słyszeć zapukanie, ciekawe modniś rzucił ku drzwiom spojrzenie, jak gdyby kogoś oczekiwał, lecz zmarszczył się, spostrzegłszy posługacza.

$$
\text { S. Jaszowski, Modniś (s. 218) }
$$

Powyższy fragment ukazuje zwyczaje prototypowego modnisia, co sygnalizuje forma czasu teraźniejszego wyrażającego habitualność. Kolejne zdania, mimo że ujęte w formę czasu przeszłego, stanowią kontynuację opowiadania będącego prezentacją zwyczajowych czynności bohatera szkicu.

W świetle przytoczonych fragmentów opowiadanie jawi się jako struktura wypowiedzi służebna wobec opisu, gdyż zapewniająca jedynie pośrednią charakterystykę typu społecznego. Zmiana kategorii gramatycznej czasu w strukturze tekstu pomaga ponadto uczynić opowiadanie bardziej dynamicznym i uwypuklić główny cel komunikatu (charakterystyka typu).

Ważną rolę ze względu na funkcję w tworzenie definicji gatunkowej szkicu fizjologicznego spełnia również dialog, który wbrew oczekiwaniom występuje dość często w strukturze tekstu analizowanej odmiany genologicznej. Forma i funkcja dialogu w szkicach fizjologicznych nie sąjednorodne:

- $\mathrm{Nu}$ - mówi jeden trochę z żydowska - ten pojedzie.

— Który? Ten w szubie - o, nie! Ma na nogach kalosze, pójdzie picchotą. Skąpiec! Czy widzisz, jaką ma czapkę starą i zasmoloną z tyłu od włosów, a spodnie u dołu pozawijane, żeby się nie zbłociły?

- Prawda!

- Panienko! Ja z panną pojadę. Ciężkie czasy, nie ma wojska — poszła piechotą.

J. I. Kraszewski, Drażkarze (s. 188)

Powyższy przykład pokazuje obecność dialogu realnego w analizowanym gatunku mowy, brak redundancji informacyjnej i sztuczności języka nie pozwala bowiem określić powyższej rozmowy mianem dialogu fingowanego ${ }^{18}$. Rozmowa — dzięki wyzyskanym elementom stylu potocznego (zdania urywane, wykrzyknienia, dialcktyzmy) - pozwala realizować zasadę mimetyzmu przedstawianych elementów rzeczywistości pozajęzykowej.

- Panna Krystyna niech się ubierze - pojedzie dziś ze mną w sąsiedztwo.

Stara panna ubiera się pół dnia w stroje, jakie ma najlepsze, ucicszona tą łaską, która się bardzo rzadko dla niej przytrafia; pokazuje się tym czasem, że już tak jest wiele osób w pojeździe, że dla panny Krystyny niepodobieństwem znaleźć miejsce.

${ }_{18}$ Rozróżnienie dialogu realnego i fingowanego wprowadził H. Markiewicz; zob. Morfologia dialogu, [w:] tenże, Wymiary dziela literackiego, Wrocław 1984, s. 60-72. 
- Panna Krystyna zostanie, bo nie ma miejsca - mówi bratowa i biedna kuzyna, żałując czasu na ubranie, musi pozostać rada nierada.

Leon Kunicki, Stare panny (s. 119)

Dialog jest tu jedynie elementem dodatkowym, przeplatającym opowiadanie. Spełnia wyraźną funkcję służebną wobec sprawozdania, przeciwdziała monotonii wywodu, dynamizuje dyskurs. Struktura dialogowa nie wnosi zatem nowych informacji do tekstu, wzmacnia jedynie weryzm przedstawianych charakterystyk.

Elementy dialogu są w szkicu fizjologicznym wyraźnie podporządkowane strukturom narracyjnym, stanowią dodatkowy pierwiastek potwierdzający weryzm opisu i opowiadania.

Przedstawione analizy pozwalają wysnuć wnioski uogólniające dotyczące szkicu fizjologicznego. Gatunek ten jest typem komunikatu o zasięgu masowym, o czym świadczy typ relacji nadawczo-odbiorczej odzwierciedlony w plaszczyźnie tekstu. Uobecnienie i zbliżenie podmiotów komunikacji służy pogłębieniu relacji nadawczo-odbiorczej, które umożliwia z kolei realizację strategii dyskursu zgodnej z intencją nadawcy. Szkic fizjologiczny jest ponadto gatunkiem mowy o nadrzędnej funkcji użytkowej, która manifestuje się kreowaniem obrazu typów społecznych. Celowi temu podporządkowane są właściwie wszystkie elementy struktury tekstu. Prymarną rolę z pewnością odgrywa opis zapewniający charakterystykę bezpośrednią danego typu. Służebną i uzupełniającą wobec opisu funkcję spełniają opowiadanie i dialog, które pogłębiają weryzm formułowanych charakterystyk i pomagają urozmaicić tok wywodu.

Wyrazistość funkcji komunikatu odzwierciedlona w strukturze stylistycznej oraz socjologiczne nacechowanie problematyki wskazują na szerokie przeznaczenie szkicu fizjologicznego i pozwalają przypisać mu niebagatelną rolę w kształtowaniu się masowego wymiaru komunikacji w XIX wieku. 